\title{
DOUTRINA
}

\section{O Divórcio em Roma na Antiguidade}

\author{
Alexandre Augusto de Castro Correa \\ Professor Titular de Direito Romano da Faculdade \\ de Direito da Universidade de São Paulo
}

\begin{abstract}
SUMARIO: 1. Os termos "repudium" e "divortium" - 2. História do divórcio em Roma - 3. Vontade dos cônjuges e divórcio - 4. Formas do divorcio - 5. Regulamentação do divórcio pelos imperadores cristãtos - 6. Direito de Justiniano - 7. Exemplos de motivos de divórcio nos fins da República.
\end{abstract}

\section{OS TERMOS “REPUDIUM" E "DIVORTIUM"}

1. O casamento romano dissolvia-se, entre outras causas, também pelo divórcio, indicado nos textos por duas expressões: "repudium" e "divortium". A primeira, entretanto, aplica-se tanto ao casamento quanto aos esponsais ("Mentio et repromissio nuptiarum futurarum"), enquanto a segunda reserva-se ao casamento já contraído. (D. 50, $16,101,1 ; 191)$.

\section{HISTÔRIA DO DIVôRCIO EM ROMA}

2. O divórcio é ato solene, tendo por fim dissolver o casamento. "Divortium autem vel a diversitate mentium dictum est vel quia in diversas partes eunt qui distrahunt matrimonium". (D. 24,2, "De divortiis et repudiis", 2).

O instituto existiu sempre, em Roma, sendo, porém, pouco usado no mais antigo período, muito embora não seja possível aceitar como verdadeira a tradição fazendo remontar a Calvísio Ruga (no ano 231 a.C.) o primeiro caso de divórcio, motivado pela esterilidade da mulher. Os dois cônjuges não tinham igual direito de se repudiarem: a mulher "in manu" não podia fazê-lo ao contrário daquela que conservara sua independência.

Se a mulher, entretanto, fosse antiga escrava manumitida pelo dono para fim de casamento, só o marido podia romper a união contraída (D. 24,2. "De d. et repudiis", 10). Aulo-Gelio, finalmente, 
observa no livro $\mathrm{X}$, cap. $\mathrm{XV}$, que o casamento dos "flamines" só se dissolve pela morte, sendo-lhes vedado o divórcio.

\section{VONTADE DOS CôNJUGES E DIVôRCIO}

3. No antigo direito o divórcio podia emanar do "pater-familias" tendo "in potestate" o marido ou a mulher. Era a consequiência do princípio proibindo aos filhos modificarem a condição do pai contra a vontade deste (Fr. Vat. $\S 116$; D. 24, 2, 4; C. 5, 17, 5). Sob Antonino, o Pio, os ascendentes perderam o direito de separar os cônjuges contra a vontade dos mesmos: "Bene concordans matrimonium separari a patre Divus Pius prohibuit" (Paulo, "Sent", V, VI, 15).

A mãe, sem "potestas", jamais podia enviar ordem de divórcio ao cônjuge de seu filho ou filha.

\section{Formas de Divórcio}

4. Antes da lei Julia "de adulteriis" não havia forma especial para o divórcio. Só na prática a mulher devolvia ao marido as chaves recebidas ao entrar no domicílio conjugal. A lei Julia, sob pena de nulidade, exigiu forma solene (D. 38, 11, 1,1). Cumpria convocar sete testemunhas púberes e cidadãs romanas, mais um liberto, encarregado de levar a declaração de divórcio, assim concebida: "Res tuas tibi habeto". A estas formalidades acrescentou-se, mais tarde, a destruição dos "acta dotalia" e a menção do divórcio nos registros competentes (D. $24,2,2,1 ; 24,2,9$ ).

Livre, a princípio, o divórcio foi depois regulamentado. Durante muito tempo o divórcio foi livre: a única sanção consistia nas retenções sobre o dote, facultadas ao marido ou na perda do prazo para a restituição daquele, conforme a culpa fosse dum ou doutro cônjuge. (Ulp., "Reg." 6,13). Esta facilidade dera lugar a grandes abusos: todos conhecem a história das mulheres romanas mudando de marido mais freqüentemente do que o Estado mudava de cônsules.

\section{Regulamentação do divórcio pelos imperadores cristãos}

5. Os imperadores cristãos procuraram regulamentar o divórcio de modo a combinar a estabilidade do casamento com as condições de boa união, devendo existir entre os cônjuges. Teodósio e Valentiniano enumeram as causas do divórcio: a mulher podia deixar o marido homicida, adúltero, ladrão, etc.* bem como aquela freqüentando circos, arenas e teatros contra proibição do marido.

* O marido podia repudiar a mulher adúltera, homicida, envenenadora, etc. 
Penalidade - Divorciando-se fora desses casos a mulher perdia o dote e a doação antenupcial, não podendo recasar-se durante cinco anos, sob pena de infâmia. Repudiando a mulher, sem motivo, - marido perdia a doação antenupcial (C. $17,8, \S \S 2,3$ e 4).

Direito de Justiniano - Justiniano continuou essa legislação: na Novela 117, Caps. 8 e 9, enumera as causas de divórcio.

No Cap. $\mathrm{X}$ proíbe o divórcio por consentimento mútuo, mas na Novela 140 revoga tal proibição. Divorciando-se, sem motivo, a mulher perde o dote e é recolhida a um mosteiro. Dois terços de seus bens são atribuídos aos filhos e um terço ao mosteiro que a recebesse. $O$ marido submetido, a princípio, só a pena pecuniária foi também recolhido a claustro, e privado de seus bens (Nov. 117, C. 13; 134, C. 1.). Depois do divórcio os filhos eram confiados ao progenitor considerado pelo juiz mais capaz de educá-los.

Justiniano determinou fossem eles entregues ao cônjuge inocente (C. 5, 24, 1. única - Nov. 117, 7).

Todos os acordos visando excluir ou limitar o divórcio são nulos, sendo impossível estipular penalidade contra o mesmo. Esta liberdade ilimitada de se divorciar foi muito criticada pelos juristas e moralistas modernos os quais acreditaram ver nela sinal claro da decadência romana. Na verdade, tal liberdade é a pedra angular na qual se baseia a concepção humanística do matrimônio por parte do direito clássico. Isto resulta claramente das fontes. Em rescrito do ano 223 o imperador Alexandre afirma:

"Libera matrimonia esse antiquitus placuit. Ideoque pacta, ne liceret divertere, non valere et stipulationes quibus poenae irrogarentur ei qui divortium fecisset, ratas non haberi constat".

D. $45,1,134,1$ - Paulo " quia inhonestum visum est vinculo poenae matrimonia obstringi sive futura sive jam contracta".

Pode-se renunciar à "societas" a qualquer tempo, sendo nula qualquer cláusula, limitando perpetuamente tal direito do sócio. A liberdade plena de divorciar foi a conseqüência inevitável pois a liberdade pessoal é muito mais afetada no matrimônio do que na sociedade.

Em contraste com os juristas gregos e orientais os jurisconsultos romanos compreenderam perfeitamente que o instrumento adequado para evitar nos matrimônios as lamentáveis conseqüências do capricho individual dos cônjuges não deve ser o direito, o qual, mesmo querendo-o, não pode impor-lhes vida pacífica e exemplar.

O Direito pode, certamente, conservar os casamentos, no sentido estritamente jurídico da palavra, mas a ética e a comunidade política não têm o menor interesse em manter uniões, as quais não passem de meras fachadas legais. Na grande maioria dos casos a subsistência coercitiva do matrimônio gera a irresistivel propensão dos cônjuges ao 
concübinato ou a outras uniōes ilegítimas, para não falar dos múltiplos expedientes imaginados pelas partes e seus advogados a fim de contornarem os preceitos da lei.

Estabilidade do Matrimônio - Não dispomos de dados seguros relativos aos efeitos sociais da clássica liberdade do divórcio em Roma.

No último século da República, é certo, o número de divórcios ultrapassou o dos tempos antigos o que não significa necessariamente decadência moral, pois o desenvolvimento da personalidade individual do homem e da mulher aumenta, inevitavelmente, as dificuldades oferecidas pela vida matrimonial permanente. Bom exemplo disto é o casamento de Cícero com Terência a qual, sob muitos aspectos, foi superior ao marido. Além disso os efeitos próprios dos tempos revolucionários, produziram graves danos para o matrimônio, sobretudo no estrato social elevado que era a sementeira donde procediam as figuras da política.

O marido de Túria declarava: "Rara sunt tam diuturna matrimonia finita morte, non divortio interrupta: nam contigit nobis ut ad annum XXXI sine offensa perduceretur".

De qualquer forma, os matrimônios de 40 anos são sempre raros. Durante o Principado a duração dos casamentos foi normal e nas inscrições da época encontramos referências a matrimônios de longa duração. No "Satiricon", de Petrono $(74,16)$ Trimalcião, falando como autêntico romano, diz: "Sugeriram-me o divórcio pelo fato de eu não ter filhos. Mas recusei separar-me pois sou homem de bem e não quero parecer frivolo ("dum bonatus ago et nolo videri levis"). A "gravitas" romana respeitava mais a sanção dos costumes do que as proibições legais.

As penas castigando os divórcios por causas frívolas não existiram durante o periodo republicano. Mas, a obrigação do marido restituir o dote atuava de certo modo à guisa de pena. Cícero passou por difíceis momentos quando obrigado a restituir o dote pertencente a Terência, o mesmo acontecendo a seu genro Dorabella quando se divorciou de Tulia. A "retentio proter liberos" produziu efeito semelhante.

No caso mencionado, da proibição estabelecida por Augusto, contra a liberta, se esta violasse a regra o casamento se dissolvia mas a mulher perdia o "conubium" necessário para contrair novo casamento.

Forma do Divórcio - Convenção não solene ou declaração dum dos cônjuges. Exigia-se sempre a cessação da vida em comum.

No caso de adultério, o marido era obrigado pela "Lex Julia de adulteris" a divorciar-se sob pena de incorrer em "lenocinium" (Caso do marido que se aproveita do adultério da mulher sem propor contra ela a competente ação de divórcio).

Exigia-se alguma prova da intenção de se divorciar. Sabemos do emprego de palavras usuais ou da remessa dum documento ("libellus 
repudii") exatamente como sabemos de palavras e cerimônias costumeiras para a instauração do casamento. Mas nada disso era legalmente necessário.

Até os fins da República a completa liberdade do Divórcio era contrariada pela opinião pública e pelo costume romano de convocar um "consilium domesticum" antes de qualquer decisão importante.

Eram também cabiveis sanções aplicadas pelo Censor. Assim, em 307 a.C. um senador perdeu o cargo pelo fato de se ter divorciado sem consultar o Conselho de Família. No último século antes de Cristo. entretanto, o Divórcio tornou-se corrente, pelo menos nas classes elevadas, a respeito de cujos costumes somente temos algumas provas.

O respeitável Cícero separou-se da mulher, depois de trinta anos de casado, para contrair novo matrimônio com mulher rica e jovem. E Catão de Útica não hesitou em casar novamente com sua mulher (da qual se divorciara), quando esta ficou viúva e rica por morte do segundo marido. O próprio Augusto se divorciou da primeira mulher, antes de se casar com Livia. A famosa inscrição da época ("Laudatio Turiae") refere quão raros eram os casamentos dissolvendo-se por morte e não por divórcio.

Sêneca, cinqüenta anos depois, nota: as mulheres contavam a idade não pelo número de cônsules, como outrora, mas pelo de maridos.

O único obstáculo eficaz contra o divórcio era constituído pelas regras governando a restituição ou a retenção do dote da mulher.

O marido podia reter parte do dote pelas seguintes causas:

a) "propter liberos": 1/6 do dote em razão de cada filho; em nenhum caso, porém, a retenção podia ultrapassar metade do dote;

b) propter mores uxoris - por conduta licenciosa da mulher; 1/8 do dote em casos leves e 1/6 em casos graves.

c) “propter res amotas" - Quando a mulher, depois de consumado o divórcio, apossava-se de coisas pertencentes ao marido, querendo, assim, reaver seu dote mediante ato de defesa privada, tal ato não se considerava "furtum"; as coisas subtraídas pela mulher não eram chamadas "res furtivae" e sim "res amote" ou "subtraídas" em atenção à dignidade do casamento impedindo a propositura entre os cônjuges duma ação infamante qual a "acto furti".

\section{DIREITO DE JUSTINIANO}

6. Justiniano reformou drasticamente a ação clássica para recuperar o dote, o qual devia ser sempre restituído e a correspondente ação tornou-se transmissível aos herdeiros da pessoa ligitimada a pro- 
pô la. Os imóveis deviam restituir-se imediatamente e os móveis no prazo dum ano. A "actio de dote" como se chama agora é fortalecida por "hypotheca generalis" sobre os bens do marido.

Assim, um marido indiferente ao divórcio poderia hesitar em perder 0 dote reciprocamente, havendo filhos, o direito de retenção do marido seria capaz de inibir a mulher. Tais motivos, entretanto, não bastariam diante da perspectiva de casamento mais rico.

Com o advento do Cristianismo como religião oficial do império era de se esperar a mudança radical no modo de encarar o divórcio.

O consentimento constituía de fato a base do casamento cristão, como do romano, mas para o cristão o poder da vontade se esgotava na criação do vínculo, excluindo a idéia pagã romana, segundo a qual o que fora criado mediante acordo pudesse dissolver-se por força de acordo contrário ou distrato. Tal era a doutrina cristã e o Império era oficialmente cristão; ele abrangia, porém, dentro de suas fronteiras, uma população mui heterogênea, boa parte da qual não obedecia ao novo ensinamento. Por isso, eram comuns as penalidades eclesiásticas contra divorciados que contraíam novo casamento. Mesmo os mais enérgicos imperadores cristãos não ousaram erradicar completamente a velha lei, procurando antes restringir sua aplicação. Impuseram penalidades cada vez mais severas (vimô-lo, já) contra o divórcio, salvo nos casos reconhecidos pelo legislador.

As causas de divórcio, admitidas por Justiniano, são as seguintes:

a) "Divortium ex justa causa", repúdio em casos determinados por lei e acarretando graves sanções a cargo do culpado;

b) "Divortium sine causa" - punido, mas válido;

c) "Divortium ex communi consensu, vedado por Justiniano, mas restabelecido por seu sucessor;

d) "Divortium bona gratia (no tempo de Justiniano) causado por motivos não imputáveis a nenhum dos cônjuges, tais como esterilidade durante três anos consecutivos, deficiência física de qualquer deles, ausência do marido por cinco anos, como prisioneiro de guerra, doença mental ou voto de castidade dum dos cônjuges. Não acarreta sanção alguma.

Portanto, mesmo o divórcio injustificado, embora punido, era válido exceto no caso da mulher culpada e condenada por Justiniano ao confinamento perpétuo em convento.

A proibição ao "divortium ex communi consensu" foi imposta em 542 por Justiniano. Mas, os costumes arraigados resistiram e cinco anos depois da morte do imperador ele foi restabelecido.

Sob este aspecto, entretanto, o Direito Romano não perdurou: a lei do casamento da Europa Ocidental estava destinada a ser ditada 
pelo Direito Canônico. Ora, este, embora de origem romanística, rejeitou inevitavelmente a concepção pagã do Divórcio. Além disso, o divórcio moderno envolve necessariamente a intervenção judicial, enquanto o divórcio romano era assunto puramente privado.

\section{EXEMPLOS DE MOTIVOS DE DIVÓRcio NOS FINS DA REPÚBLICA}

7 Não faltam; e Carcopino em "La vie quotidienne à Rome à l'apogée de l'Empire”, (pp. 118-124), nó-los oferece.

Mesmo nos tempos lendários, aos quais a Roma clássica amavase reportar em pensamento, a fim de neles descobrir imagem de si própria, próxima do ideal, que se afastava sempre mais, o casamento nunca fora indissolúvel. No casamento "cum manu", dos primeiros séculos, o repúdio do marido pela mulher, colocada sob a autoridade daquele, era impossível; o repúdio da mulher pelo marido era, pelo contrário, prerrogativa deste.

Sobre a futilidade dos motivos de Divórcio, nos fins da República. Ver Carcopino, op. cit. p. 119.

O casamento "sine manu" concedeu também à mulher a faculdade de anular à vontade as uniões contraídas. Em conseqüência, na época de Cícero, o "divortium communi consensu" ou por vontade unilateral tornou-se moeda corrente nas relações de família.

Sylla, na velhice, casara-se pela quinta vez com uma jovem divorciada, Valéria, meia-irmã do orador Hortênsio.

Pompeu, duas vezes viúvo, de Emília e Júlia, divorciara-se primeiro daquela e depois desta, duas vezes, portanto; de Antístia, mais tarde, com quem se casara para obter as boas graças do pretor, do qual dependia o mandado de imissão na posse de sua imensa fortuna paterna. $\mathrm{O}$ apego, porém, da terceira mulher ameaçou entravar a carreira política de Pompeu, que se divorciou, finalmente, de Múcia, cuja conduta deixaria a desejar durante a longa ausência do marido, nas campanhas no ultramar.

Viúvo de Cornélia, César repudiou Pompéia, com a qual se casara, depois da morte da filha de Cinna, pelo simples motivo de, mesmo inocente, a mulher de César não dever ser alvo de suspeitas.

Sem falsos pudores, Cícero, aos 57 anos de idade, para restaurar suas finanças com dote da jovem e rica Publília hesitou, depois de trinta anos de vida em comum, em repudiar Terência, mãe de seus filhos, a qual, aliás, parece ter suportado serenamente o infortúnio, pois deveria casar-se duas vezes ainda, primeiro com Salústio e depois com Messala Corvino, morrendo mais que centenária. 